\title{
Does static magnetic field-exposure induced oxidative stress and apoptosis in rat kidney and muscle? Effect of vitamin $\mathrm{E}$ and selenium supplementations
}

\author{
Soumaya Ghodbane, Aida Lahbib, Mohamed Ammari, Mohsen Sakly and Hafedh \\ Abdelmelek
}

Laboratoire de Physiologie Intégrée, Faculté des Sciences de Bizerte, 7021 Jarzouna, Tunisia

\begin{abstract}
Static magnetic fields (SMFs) effect observed with radical pair recombination is one of the well-known mechanisms by which SMFs interact with biological systems. Our aim was to study whether SMF induces oxidative stress and apoptosis in rat tissues and to evaluate the possible protector effect of selenium (Se) and vitamin E (vit E) supplementations. Rats were randomly divided into control, SMF-exposed, Se-treated, vit E-treated, SMF exposed rats and co-treated with Se, and SMF exposed rats and co-treated with vit E. After animal sacrifice, catalase (CAT) activity and malondialdehyde (MDA) concentration were measured and apoptosis inducing factor (AIF) immunohistochemical labeling was performed in kidney and muscle. Exposure of rats to SMF (128 $\mathrm{mT}, 1 \mathrm{~h}$ /day for 5 days) increased the MDA concentrations (+25\%) and CAT activities (+34\%) in kidney but not in muscle. By contrast, the same treatment failed to induce a caspase-independent pathway apoptosis in both tissues. Interestingly, Se pre-treatment inhibited the increase of MDA concentrations and CAT activities in kidney in SMF-exposed rats. However, vit E administration corrected only MDA levels in rat kidney. In conclusion, exposure to SMF induced oxidative stress in kidney that can be prevented by treatment with Se or vit E.
\end{abstract}

Keywords: Static magnetic field - Oxidative stress - Apoptosis-inducting factor - Selenium - Vitamin E

\section{Introduction}

The influence of static magnetic fields (SMFs) or modulated magnetic fields (MFs) on biological systems has been a topic of considerable interest for many years (Hong1995; Rosen 2003). One reason why it is extremely important to deeply understand the true mode of action of MFs on living organisms, is the need to protect human health in consideration of the probable future introduction of new technologies and the therapeutical use of SMFs. At the current state of knowledge, the biological effects, both in vivo and in vitro, of SMFs have yet to be unequivocally interpreted. Accumulating evidences have shown that SMF treatments

Correspondence to: Ghodbane Soumaya, Laboratoire de Physiologie Intégrée, Faculté des Sciences de Bizerte, Jarzouna 7021, Tunisia

E-mail: ghodhbanes@yahoo.fr influence lipid peroxidation and antioxidant defence system, induce apoptosis, genotoxicity, and cell differentiation in various kinds of cells (Dini and Abbro 2005; Feychting et al. 2005). Sub-acute exposure to SMF (128 mT, $1 \mathrm{~h} /$ day, during 5 consecutive days) induced sympathetic neurons system hyperactivity associated with hypoxia-like status (Abdelmelek et al. 2006) and elevated plasma corticosterone and metallothionein concentrations and enhanced apoptosis (Chater et al. 2004, 2005). Hashish et al. (2008) indicated that there is a relation between the exposure to SMF and the oxidative stress through distressing redox balance leading to physiological disturbances. Previous data implicated the SMF in free radical production, like superoxide anions in different cells and organs (Zmyslony et al. 1998; Kula et al. 2000; Okano 2008).

Sub-acute exposure to SMF (128 mT; $1 \mathrm{~h}$ /day from day 6 to day 19 of pregnancy) induced an increase of liver GSH content (Chater et al. 2006). Similar results were reported 
by Ghodbane et al. (2011b) who showed that liver GSH concentrations were significantly higher in SMF exposed rats than in the controls, indicating an adaptive mechanism to electromagnetic pollution.

Moreover, exposure of rats to SMF ( $128 \mathrm{mT}, 1 \mathrm{~h} /$ day during 30 consecutive days) increased the 8 -oxo-7,8-dihydro2'-deoxyguanosine (8-oxodGuo) concentration in kidney, while this biomarker of DNA oxidation remained unaffected in liver and brain (Amara et al. 2007, 2009). Interestingly, Chater et al. (2005) concluded that sub-acute exposure to SMF (128 mT) induced apoptosis in thymus in female rats, using the TdT-mediated dUTP nick-end labeling (TUNEL) assay.

Apoptosis, spontaneous and induced, has been reported to be influenced by SMFs (Fanelli et al. 1999; Teodori et al. 2002; Chionna et al. 2003, 2005).

Up until now, few studies have investigated the effects of SMF on expression of genes, especially those involved in apoptosis. Previous research has shown that SMF exposure alone extensively modulated the expression of bcl-2, bax, p53, and hsp70 genes (Tenuzzo et al. 2009). SMF (6 mT) can induce apoptosis and alter cell cycle in Jurkat cells via a p53-independent pathway (Ahmadianpour et al. 2013). It can be suggested that the magnetic fields may induce the apoptosis and alter the cell population in different cell cycle phases of Jurkat cells via changing the $\mathrm{Ca}^{2+}$ fluxes through cell membranes and play a role in free radical formation (Ahmadianpour et al. 2013). Joubert et al. (2008) supported the hypothesis that microwaves $(900 \mathrm{MHz})$, could be capable of inducing neuronal apoptosis through the apoptosis-inducing factor (AIF) pathway. AIF, a mitochondrial intermembrane flavoprotein that can induce caspase-independent peripheral chromatin condensation and DNA fragmentation, has been widely implicated in neuronal apoptosis (Cregan et al. 2002). Previously, we have demonstrated that sub-acute exposure to SMF (128 mT) induced apoptosis in hepatic cells through a caspase-independent death signaling pathway induced by the death-promoting factor AIF (Ghodbane 2011). Likewise, sub-acute exposure to SMF (128 mT; $1 \mathrm{~h} /$ day for 5 days) induced a decrease of selenium levels in kidney, muscle and brain with a decrease of GPx activities in kidney and muscle. SMF-exposure also decreased plasmatic vitamin E (vit E, $\alpha$-tocopherol) and retinol in rats (Ghodbane et al. 2011a). Indeed, the decrease of selenium and vit E concentrations could play an important role in the disruption of antioxidant response leading to disequilibria in the oxidative balance.

In the present study, our aim was to investigate whether sub-acute exposure to moderate-intensity SMFs could induce oxidative stress and apoptosis through a caspaseindependent death signaling pathway (AIF) in rat kidney and muscle. Also, we evaluated the possible protector effect of selenium (Se) and vit E supplementations.

\section{Materials and Methods}

\section{Animals}

Adult Wistar male rats (SIPHAT, Tunisia), weighing at the beginning of the experiment 130-150 g were randomly divided into the following groups: control $(n=6)$, SMFexposed (128 $\mathrm{mT}$; $1 \mathrm{~h} /$ day for 5 days $)(n=6)$, Se-treated $\left(\mathrm{Na}_{2} \mathrm{SeO}_{3}, 0.2 \mathrm{mg} / \mathrm{l}\right.$, in drinking water for 4 weeks $)(n=6)$, Se-treated and SMF-exposed (Se for 4 weeks and SMF during the last 5 consecutive days) $(n=6)$, vit E-treated (DL a-tocopherol acetate, $150 \mathrm{mg} / \mathrm{kg}$, per os for 5 days $)(n=6)$ and vit $\mathrm{E}$ administered and co-exposed rats (vit $\mathrm{E}$ and SMF during 5 consecutive days) $(n=6)$. Animals were housed in group of six in cages at $25^{\circ} \mathrm{C}$, under a $12: 12 \mathrm{~h}$ light/dark cycle, with free access to food and water. Animals were cared for, under the Tunisian code of practice for the Care and Use of Animals for Scientific Purposes. The experimental protocols were approved by the Faculty Ethics Committee (Faculté des Sciences de Bizerte, Tunisia).

\section{Exposure system}

Lake Shore electromagnets (Lake Shore Cryotronic, Inc., Westerville Ohio, USA) are compact electromagnets suited for many applications such as magnetic resonance demonstrations. Water-cooled coils provide excellent field stability and uniformity when high power is required to achieve the maximum field capability for the electromagnet (Fig. 1).

\section{SMF exposure}

SMF was measured and standardized in the total floor area of the plexiglas cage $(20 \times 10 \times 20 \mathrm{~cm})$ at $128 \mathrm{mT}$. The two bobbins of the Lake Shore system were separated by $12 \mathrm{~cm}$. Male rats were exposed to the SMF, $1 \mathrm{~h} /$ day (between 9-12 h) during 5 consecutive days. The cage in the Lake Shore system contained two rats for each assay. The control rats were placed under the same conditions without applying the SMF (Abdelmelek et al. 2006).

\section{Tissue samples}

Rats were sacrificed by decapitation in postprandial state. Kidney and muscle samples were immediately removed, frozen and stored at $-80^{\circ} \mathrm{C}$ until assays.

\section{Malondialdehyde (MDA) assay}

Lipid peroxidation (LPO) was measured in kidney and muscle samples by the thiobarbituric acid reacting substance (TBARS) and was expressed in terms of MDA content (Placer et al. 1966). Sample aliquots were incubated 


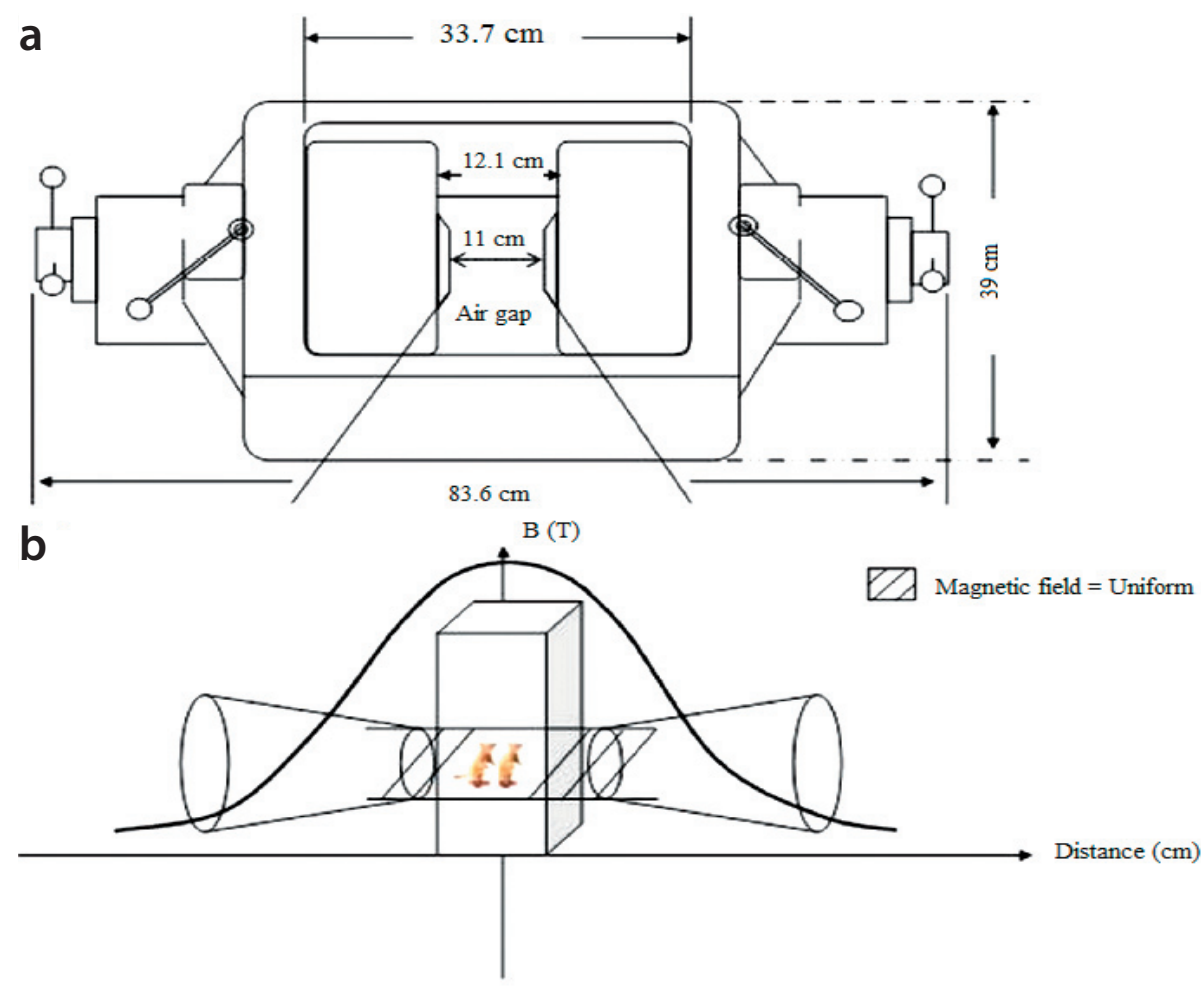

C

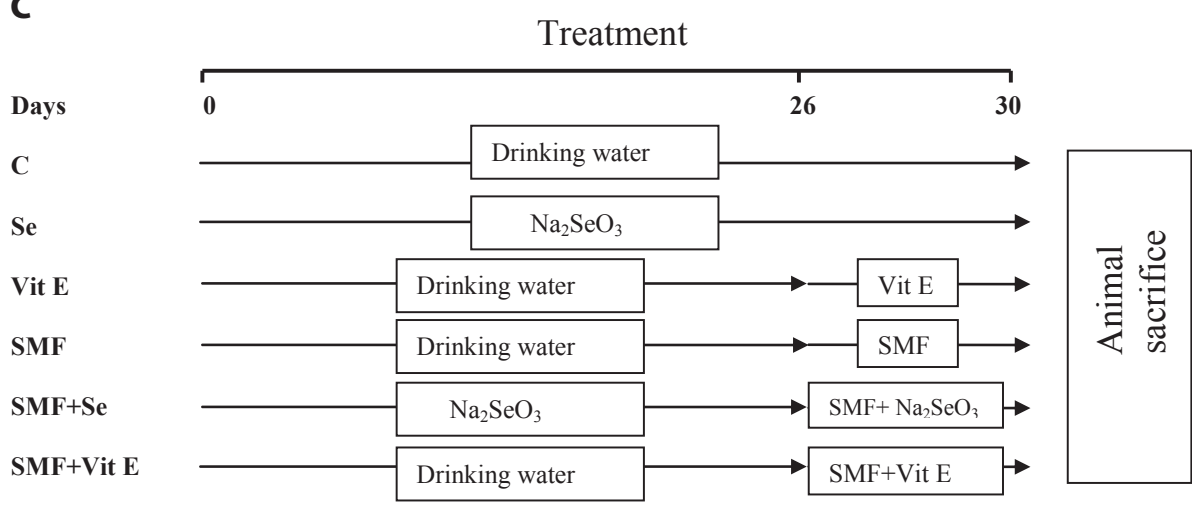

Figure 1. Front view of the electromagnet, model EM4-HVA (a) and magnetic field propagation (b). c. Treatment and exposure protocols for C (control), Se (Se-supplemented), Vit E (vitamin E-supplemented), SMF (SMF-exposured), SMF-Se (co-exposed rats to SMF and Se), SMF-Vit E (co-exposed rats to SMF and Vit E) groups. Vit E, vitamin E; SMF, static magnetic field.

with $10 \%$ trichloroacetic acid and $0.67 \%$ thiobarbituric acid. The mixture was heated on a boiling water bath for 30 min, an equal volume of $n$-butanol was added, and the final mixture was centrifuged; the organic phase was collected for fluorescence measurements. Samples assayed for MDA contained $1 \mathrm{mM}$ butylated hydroxytoluene (BHT) in order to prevent artefactual LPO during the boiling step. The absorbance of samples was determined at $532 \mathrm{~nm}$. Results were expressed as nmol MDA/mg protein.

\section{Catalase (CAT) activity}

CAT activity was measured in kidney and muscle samples at $20^{\circ} \mathrm{C}$ according to Aebi (1984). The homogenate was incubated with ethanol (10\%) and Triton (10\%). Activity was assayed at $25^{\circ} \mathrm{C}$ by determining the rate of degradation of $\mathrm{H}_{2} \mathrm{O}_{2}$ at $240 \mathrm{~nm}$ in $10 \mathrm{mM}$ of potassium phosphate buffer ( $\mathrm{pH}$ 7.0). The extinction coefficient of $43.6 \mathrm{mM} / \mathrm{cm}$ was used for calculation. One unit is defined as $1 \mathrm{pmol}$ of $\mathrm{H}_{2} \mathrm{O}_{2}$ 
consumed per minute and the specific activity is reported as units per milligram of protein.

\section{AIF immunohistochemical labeling in rat kidney and muscle}

Kidney and muscle samples were fixed overnight at room temperature in paraformaldehyde $10 \%$ in $0.1 \mathrm{M}$ phosphate buffer, $\mathrm{pH}$ 7.4. The samples were dehydrated with ethanol and toluene series and embedded in paraffin. Sections were deparaffinized in toluene and hydrated with ethanol. Antigenic determinants were masked by heat for $40 \mathrm{~min}$. Then, sections were incubated in peroxidase blocking solution and Protein Block for 5 minutes at room temperature. To determine the presence of AIF-positive nuclei (red), sections were incubated in Rabbit Anti-Human/Mouse/Rat AIF Antigen Affinity purified Polyclonal Antibody (Catalog \# AF1457) at $10 \mu \mathrm{g} / \mathrm{ml}$ for $1 \mathrm{~h}$ at room temperature. Then, sections were incubated in Secondary Antibody (Post Primary Block) for $30 \mathrm{~min}$, in tertiary Antibody (NovoLink Polymer) for $30 \mathrm{~min}$ and in amino-ethyl carbasol (AEC) for $20 \mathrm{~min}$. Cells were counterstained with hematoxylin (blue).

Three independent experiments were performed.

\section{Data presentation and statistical analysis}

Data are expressed as means of six animals per group \pm S.E.M. The differences between groups were analyzed using the Mann-Whitney $U$ test. A $p$ value less than 0.05 were considered significant.

\section{Results}

MDA concentrations increased $(1.58 \pm 0.04$ vs. $1.26 \pm 0.24$ $\mathrm{nmol} / \mathrm{mg}$ prot, $p<0.05)$ in kidney and remained unchanged $(0.67 \pm 0.05$ vs. $0.74 \pm 0.09 \mathrm{nmol} / \mathrm{mg}$ prot, $p>0.05)$ in muscle of SMF-exposed rats $(128 \mathrm{mT}, 1 \mathrm{~h}$ /day during 5 consecutive days) compared to control group (Table 1). Moreover, in treated rats CAT activity increased in kidney (178 \pm 5 vs. 133 $\pm 17 \mathrm{U} / \mathrm{mg}$ prot, $p<0.05)$ but not in muscle $(2.84 \pm 0.22 \mathrm{vs}$. $3.02 \pm 0.62 \mathrm{U} / \mathrm{mg}$ prot, $p>0.05$ ) (Table 2 ).

Using double staining with hematoxylin and AIF our results indicated the absence of AIF-positive nuclei in kidneys (Fig. 2) or muscle (Fig. 3) of SMF-exposed rats suggesting that SMF failed to induce apoptosis through a caspase-independent pathway in kidneys or muscle cells. Besides, no AIF-positive nuclei were observed in kidneys (Fig. 2) or muscle (Fig. 3) of supplemented rats with Se or vit E.

Supplementation with $\mathrm{Se}\left(\mathrm{Na}_{2} \mathrm{SeO}_{3}, 0.2 \mathrm{mg} / \mathrm{l}\right.$, during 30 consecutive days, per os) restored MDA concentrations (1.32 \pm 0.15 vs. $1.26 \pm 0.24 \mathrm{nmol} / \mathrm{mg}$ prot, $p>0.05$ ) (Table 1) and corrected the rise of the catalase activity in kidneysof SMFexposed rats $(119 \pm 6$ vs. $133 \pm 17 \mathrm{U} / \mathrm{mg}$ prot, $p>0.05)$ (Table 2). Besides, vit E administration (150mg/kg DLa-tocopherolacetate during 5 days) restored ( $1.23 \pm 0.05$ vs. 1.26 $\pm 0.24 \mathrm{nmol} / \mathrm{mg}$ prot, $p>0.05$ ) MDA concentrations (Table 1) but failed to correct $(170 \pm 15 v s .133 \pm 17 \mathrm{U} / \mathrm{mg}$ prot, $p<0.05)$ the catalase activity in kidneys of SMF-exposed rats (Table 2).

Table 1. Effects of selenium and vitamin E administration on the MDA levels of SMF-exposed rats

\begin{tabular}{lccccccc}
\hline & \multirow{2}{*}{ Tissue } & \multicolumn{7}{c}{ Group } \\
\cline { 3 - 8 } & & $\mathrm{C}$ & $\mathrm{Se}$ & Vit E & SMF & SMF+Se & SMF+Vit E \\
\hline $\begin{array}{l}\text { MDA } \\
\text { (nmol/mg prot) }\end{array}$ & Kidney & $1.26 \pm 0.24$ & $1.28 \pm 0.13$ & $1.19 \pm 0.09$ & $1.58 \pm 0.04^{*}$ & $1.32 \pm 0.15$ & $1.23 \pm 0.05$ \\
\cline { 2 - 9 } & Muscle & $0.74 \pm 0.09$ & $0.84 \pm 0.18$ & $0.73 \pm 0.10$ & $0.67 \pm 0.05$ & $0.81 \pm 0.05$ & $0.63 \pm 0.11$ \\
\hline
\end{tabular}

Data represent the means \pm S.E.M. of six animals per group. ${ }^{\star} p<0.05$, compared to control (C). SMF, static magnetic field; Se, selenium; vit $\mathrm{E}$, vitamin $\mathrm{E}$.

Table 2. Effects of selenium and vitamin E administration on the catalase activities of SMF-exposed rats

\begin{tabular}{lccccccc}
\hline & \multirow{2}{*}{ Tissue } & \multicolumn{7}{c}{ Group } \\
\cline { 3 - 8 } & & $\mathrm{C}$ & $\mathrm{Se}$ & Vit E & SMF & SMF+Se & SMF+Vit E \\
\hline Catalase & Kidney & $133.08 \pm 17$ & $120.11 \pm 7$ & $131.02 \pm 29$ & $178.14 \pm 5^{*}$ & $119.05 \pm 6$ & $170.02 \pm 15^{*}$ \\
\cline { 2 - 8 } (U/mg prot) & Muscle & $3.02 \pm 0.62$ & $2.78 \pm 0.26$ & $2.92 \pm 0.40$ & $2.84 \pm 0.22$ & $2.82 \pm 0.42$ & $2.52 \pm 0.44$ \\
\hline
\end{tabular}

Data represent the means \pm S.E.M. of six animals per group. ${ }^{\star} p<0.05$, compared to control (C). SMF, static magnetic field; Se, selenium; vit E, vitamin $\mathrm{E}$. 

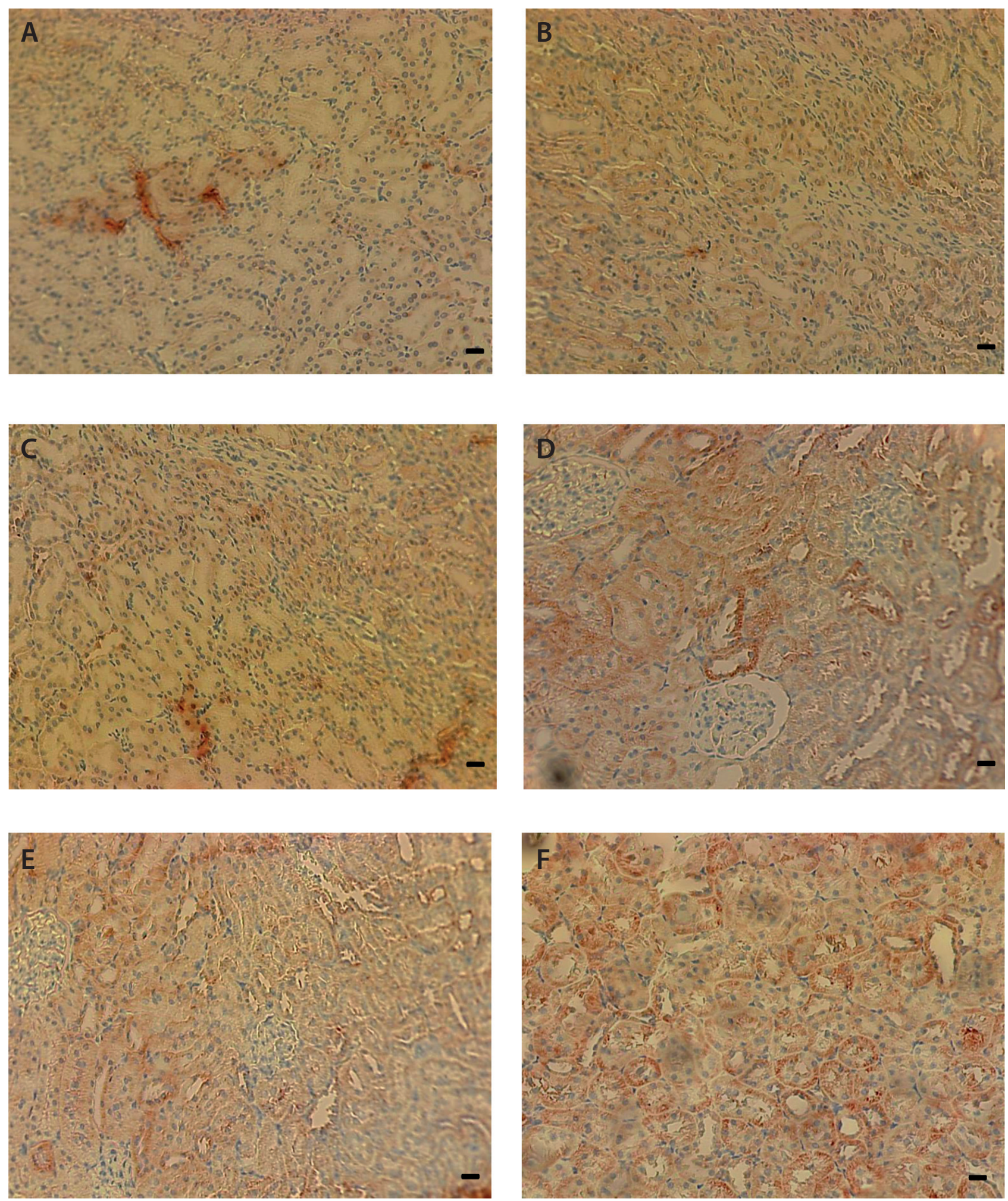

Figure 2. Photomicrographs of sections of kidney from control (A), Se-supplemented (B), vit E-supplemented (C), SMF-exposured (D), co-exposed rats to SMF and Se (E), and co-exposed rats to SMF and vit $\mathrm{E}(\mathbf{F})$ (magnification $\times 100$, scale bar $20 \mu \mathrm{m})$. Immunohistochemical labeling was performed (apoptosis-inducing factor (AIF) labeling). For more abbreviations see Fig. 1. 

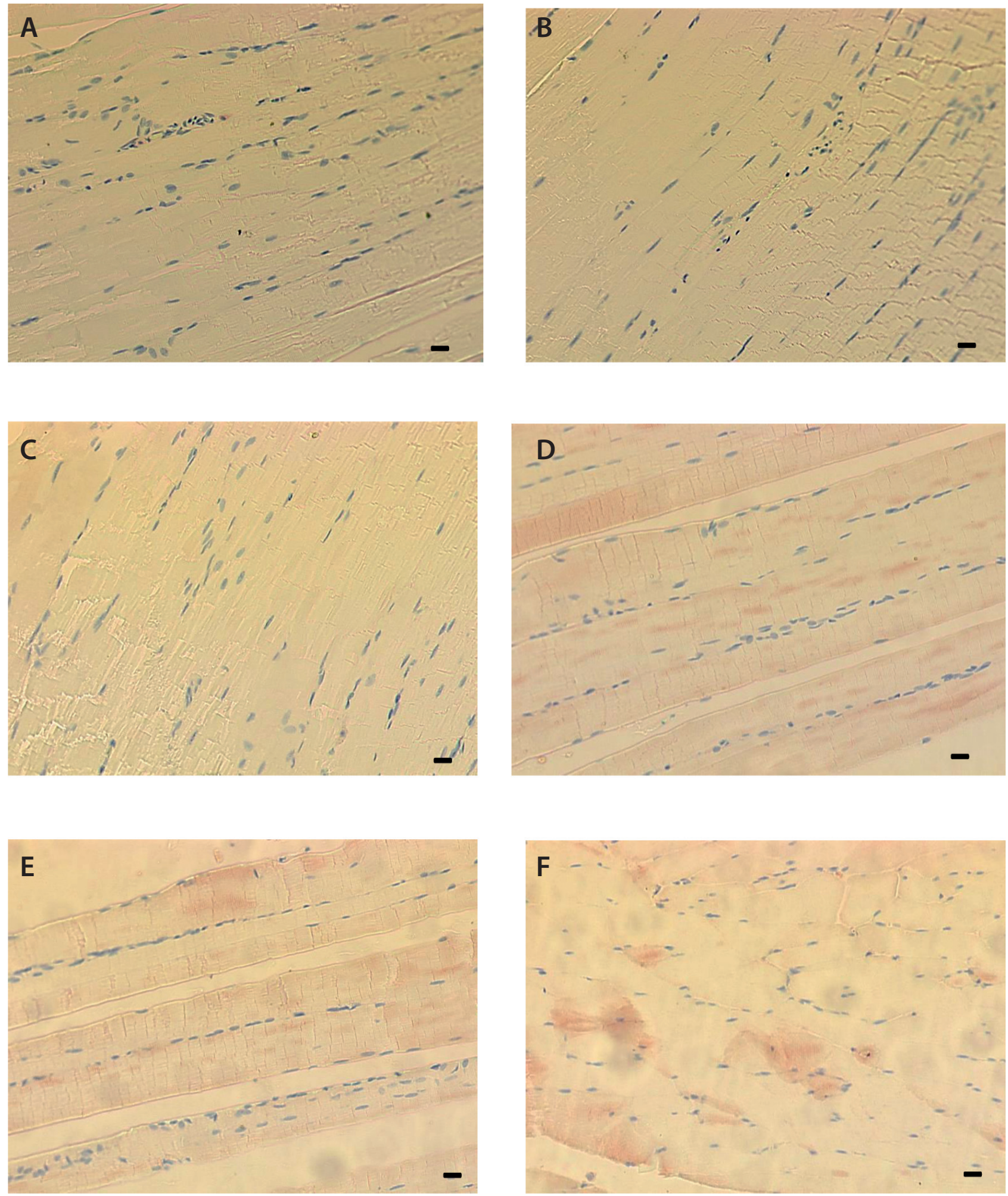

Figure 3. Photomicrographs of sections of muscle from control (A), Se supplemented (B), vitamin E supplemented (C), SMF-exposure (D), co-exposed rats to SMF and Se (E), and co-exposed rats to SMF and vit E (F) (magnification $\times 100$, scale bar $20 \mu \mathrm{m}$ ). Immunohistochemical labeling was performed (apoptosis-inducing factor (AIF) labeling). For more abbreviations see Fig. 1. 


\section{Discussion}

In the present study, we found that exposure to SMF (128 mT; $1 \mathrm{~h}$ /day during 5 days) increased MDA concentrations and catalase activities in kidney of rats indicating oxidative stress status. However, these parameters remained unchanged in muscle. In our laboratory, Abdelmelek et al. (2006) reported that SMF (128 $\mathrm{mT})$ induces hypoxia-like status associated with sympathetic hyperactivity indicating a stress induced by this treatment. The mechanism by which SMF induced oxidative stress in rat tissues is not well understood. We hypothesized that SMF exposure is associated with free radical production via Fenton reaction, which is the iron-catalyzed oxidation of hydrogen peroxide $\left(\mathrm{H}_{2} \mathrm{O}_{2}\right)$ (Connor and Menzies 1995; Markesbery 1997; Koppenol 2001; Ghodbane al. 2013). There are several reports showing that moderate SMF could influence the ROS modulation (generation/reduction) from enzymatic reactions in cell-free solutions. The SMF increases the concentration and/or lifetime of free radicals that escape from the radical pair so that the critical radical concentration, needed to initiate membrane damage and cause cell lysis, is reached sooner (Okano 2008; Ghodbane et al. 2013).

The SMF effects play significant roles in the endogenous and exogenous ROS modulation in biological systems, in vitro and in vivo. Aristarkhov et al. (1983) demonstrated an increase of lipid peroxidation level in liposomes (1,2dioleophosphatidylcholine) exposed to SMF (8 mT). SMF, under in vitro chemical stimulation, can influence lipid peroxidation kinetics in liposomes and enhance the production of oxygen free radicals in human red blood cells (Lalo et al. 1994; Chignell and Sik 1998). Previous studies by Amara et al. $(2006,2007,2009)$ showed an increase in MDA level in male rat testis, hippocampus, liver and kidney after exposure to SMF (128 mT, $1 \mathrm{~h}$ /day during 30 consecutive days). However, Ghodbane et al. (2011a) showed that SMF exposure failed to alter plasma TBARs and total thiol groups, indicating an adaptive mechanism to slight oxidative stress caused by electromagnetic field as previously shown by Chater et al. (2006). Our investigations showed that MDA concentrations remained unchanged in muscle of rats. The cellular and molecular modifications induced when SMFs interact with biological materials are, however, dependent on the duration of exposure, intensity, tissue penetration and the type of cells (Walleczek and Liburdy1990).

Antioxidant enzymes are involved in the defense system against free radical-mediated tissue or cellular damage (Allen 1991). In our laboratory, Amara et al. (2006, 2007, 2009) showed that sub-chronic exposure to SMF (128 mT, $1 \mathrm{~h}$ /day during 30 consecutive days) decreased glutathione peroxidase (GPx), CAT and superoxide dismutase (SOD) activities in liver, kidneys, frontal cortex and the gonad. Moreover, Ghodbane et al. (2011b) demonstrated that sub- acute exposure to SMF decreased GPx activity in kidney and muscle of SMF-exposed rats. The decrease of GPx activity is associated to the increase of SOD activity in rat liver.

Our investigation reveals that the increase in MDA levels is associated to the increase of CAT activity indicating oxidative stress in kidneys of SMF-exposed rats; this effect was related in part to ROS. It has been proposed that moderate levels of ROS can induce an increase in antioxidant enzyme levels, whereas very high level of these reactants was shown to attenuate antioxidant enzyme activities (Brydon et al. 2000). Moreover, possible explanation of this phenomenon is offered by hypothesis suggesting that magnetic fields may increase expression of some proteins (Goodman and Blank 2002).

Based on advanced studies of SMF effects on oxidative stress reactions, the potentially hazardous effect of SMF on living organisms is that exposure to SMF can increase the activity, concentration, and life time of paramagnetic free radicals, which might cause oxidative stress, genetic mutation, and/or apoptosis (Mohtat et al. 1998; Zhang et al. 2003; Okano 2008; Dini 2010).

SMF induced a cell cycle arrest within the G2/M phase, and the reduction in the survivin protein level was associated with the downregulated expression of $\mathrm{Cdc} 2$, a cyclin $\mathrm{B}$-dependent kinase that is necessary for the entry into the $M$ phase (Lin et al. 2014). Natural SMF upregulates caspase 9 and downregulates Bel-2 expression, which results in higher level of active caspase 3 to trigger apoptosis in cells (Li et al. 2014). In our laboratory, exposure of rats to SMF (128 mT, $1 \mathrm{~h} /$ day during 30 consecutive days) elevated the 8-oxodGuo in kidneys (Amara et al. 2007). Chater et al. (2005) concluded that sub-acute exposure to SMF (128 mT) induced apoptosis in thymus but not in the liver and kidney in female rats. Interestingly, sub-acute exposure to SMF (128 mT) induced apoptosis in hepatic cells through a caspase-independent death signaling pathway induced by the death-promoting factor AIF (Ghodbane 2011).

In order to investigate whether SMF interferes with the apoptotic program not only by modulating $[\mathrm{Ca} 2+]_{\mathrm{i}}$ (Dini and Abbro 2005; Kim et al. 2005; Pagliara et al. 2005; Saunders 2005), but alsoby altering the expression of proor anti-apoptotic genes whose dis-regulation leads to an altered rate of apoptosis, we studied the expression of AIF in kidneys and muscle of exposed ratsto $128 \mathrm{mT} \mathrm{SMF} \mathrm{for} 5$ days. In the caspase-independent cell death pathway, DNA fragmentation and chromatin condensation are triggered by the AIF. This intramitochondrial flavoprotein is released from the mitochondria in response to apoptosis-inducing signals and is translocated to the nucleus (Susin et al. 1996; Loeffler and Kroemer 2000).

Our investigations indicated that sub-acute exposure to SMF $(128 \mathrm{mT})$ failed to induce the translocation of AIF from mitochondria to the nucleus indicating the absence 
of apoptotic effects of SMF in kidneys and muscle of exposed rats. Both induced and spontaneous apoptosis have been reported to be influenced by SMF exposure. However, some reports have failed to detect any apoptotic effect for SMFs (Teodori et al. 2002a, 2002b, 2006).

We have previously shown that SMF (128 $\mathrm{mT} ; 1 \mathrm{~h} /$ day for 5 consecutive days) decreased plasmatic a-tocopherol and retinol in rats. This decrease could play an important role in the disruption of antioxidant response leading to disequilibria in the oxidative balance (Ghodbane et al. 2011a). Sub-acute exposure to SMF (128 mT) caused also a depletion of selenium levels in kidney, muscle and brain. Consequently, the activity of selenium-dependent glutathione peroxidase was found to be lower in kidney and muscle of SMF-exposed rats. The decrease of GPx activity in SMF exposed-rats could be related to the selenium depletion, indicating oxidative stress in rat tissues (Ghodbane et al. 2011b).

Regarding the fate of $\mathrm{Se}$ and vit $\mathrm{E}$ administrations in SMF-exposed rats, it may be assumed that these elements minimize the oxidative stress induced by SMF in rat tissues. Interestingly, our data showed that selenium supplementation restores the MDA concentrations and CAT activities in rat kidney, while, vit $\mathrm{E}$ administration corrected only MDA concentrations.

In conclusion, data from this study revealed that sub-acute exposure to SMF induced oxidative stress in kidney of rats but not in muscle. However, the same treatment failed to induce apoptosis through a caspase-independent death signalling pathway in rat kidney and muscle. Interestingly, selenium and vitamin $\mathrm{E}$ supplementations minimize the adverse effect of oxidative stress induced by SMF in rat kidney.

\section{References}

Abdelmelek H., Molnar S., Servais. S., Cottet-Emard J. M., Pequignot J. M., Favier R., Sakly M. (2006): Skeletal muscle HSP72 and norepinephrine response to static magnetic field in rat. J. Neural. Transm. 113, 821-827 http://dx.doi.org/10.1007/s00702-005-0364-7

Aebi H. (1984): Catalase in vitro. Methods Enzymol. 105, 121-126 http://dx.doi.org/10.1016/S0076-6879(84)05016-3

Ahmadianpour M. R., Abdolmaleki P., Mowla S. J., Hosseinkhani S. (2013): Static magnetic field of $6 \mathrm{mT}$ induces apoptosis and alters cell cycle in p53 mutant Jurkat cells. Electromagn. Biol. Med. 32, 9-19

http://dx.doi.org/10.3109/15368378.2012.692748

Allen R. G. (1991): Oxygen reactive species and antioxidant responses during development: the metabolic paradox of cellular differentiation. Proc. Soc. Exp. Biol. Med. 196, 117629

Amara S., Abdelmelek H., Garrel C., Guiraud P., Douki T., Ravanat J. L., Favier A., Sakly M., Ben Rhouma K. (2006): Effects of subchronic exposure to static magnetic field on testicular function in rats. Arch. Med. Res. 37, 947-952 http://dx.doi.org/10.1016/j.arcmed.2006.06.004

Amara S., Abdelmelek H., Garrel C., Guiraud P., Douki T., Ravanat J. L., Favier A., Sakly M., Ben Rhouma K. (2007): Zinc supplementation ameliorates staticmagnetic field-induced oxidative stress in rat tissues. Environ. Toxicol. Phar. 23,193-197 http://dx.doi.org/10.1016/j.etap.2006.09.001

Amara S., Douki T., Garel C., Favier A., Sakly M., Rhouma K. B., Abdelmelek H. (2009): Effects of static magnetic field exposure on antioxidative enzymes activity and DNA in rat brain. Gen. Physiol. Biophys. 28, 260-265

http://dx.doi.org/10.4149/gpb_2009_03_260

Aristarkhov V. M., Klimenko L. L., Deev A. I., Ivanekha A. A. (1983): Effects of constant magnetic field on peroxide oxidation of lipid in phospholipid membranes. Biophysica 28, 800-806

Brydon L., Petit L., Delagrange P., Strosberg A. D., Jockers R. (2000): Functional expression of MT2 (Mel1b) melatonin receptors in human PAZ6 adipocytes. Endocrinology 142, $4264-4271$

http://dx.doi.org/10.1210/endo.142.10.8423

Chater S., Abdelmelek H., Sakly M., Rhouma K. (2004): Effects of sub-acute exposure to magnetic field on synthesis of plasma corticosterone and liver metallothionein levels in female rats. Pak. J. Med. Sci. 20, 219-223

Chater S., Abdelmelek H., Couton D., Joulin V., Sakly M., Ben Rhouma K. (2005): Sub-acute exposure to magnetic field induced apoptosis in thymus female rats. Pak. J. Med. Sci. 21, 292-297

Chater S., Abdelmelek H., Douki T., Garrel C., Favier A., Sakly M., Ben Rhouma K. (2006): Exposure to static magnetic field of pregnant rats induces hepatic GSH elevation but not oxidative DNA damage in liver and kidney. Arch. Med. Res. 37, 941-946

http://dx.doi.org/10.1016/j.arcmed.2006.05.010

Chignell C. F., Sik R. H. (1998): The effect of static magnetic fields on the photohemolysis of human erythrocytes by ketoprofen. Photochem. Photobiol. 67, 591-595

http://dx.doi.org/10.1111/j.1751-1097.1998.tb09459.x

Chionna A., Dwikat M., Panzarini E., Tenuzzo B., Carla E.C., Verri T., Pagliara P., Abbro L., Dini L. (2003): Cell shape and plasma membrane alterations after static magnetic fields exposure. Eur. J. Histochem. 47, 299-308

Chionna A., Tenuzzo B., Panzarini E., Dwikat M., Abbro L., Dini L. (2005): Time-dependent modifications of Hep G2 cells during exposure to Static Magnetic Fields. Bioelectrmagnetics 26, 275-286

http://dx.doi.org/10.1002/bem.20081

Connor J. R., Menzies S. L. (1995): Cellular management of iron in the brain. J. Neurol. Sci. 134, 33-44 http://dx.doi.org/10.1016/0022-510X(95)00206-H

Cregan S. P., Fortin A., MacLaurin J. G., Callaghan S. M., Cecconi F., Yu S. W., Dawson T. M., Dawson V. L., Park D. S., Slack R. S. (2002): Apoptosis-inducing factor is involved in the regulation of caspase-independent neuronal cell death. J. Cell Biol. 158, 507-517

http://dx.doi.org/10.1083/jcb.200202130

Dini L., Abbro L. (2005): Bioeffects of moderate-intensity static magnetic fields. Micron 36, 195-217 
http://dx.doi.org/10.1016/j.micron.2004.12.009

Dini L. (2010): Phagocytosis of dying cells: influence of smoking and static magnetic fields. Apoptosis 15, 1147-1164 http://dx.doi.org/10.1007/s10495-010-0490-z

Fanelli C., Coppola S., Barone R., Colussi C., Gualaldi G., Volpe P., Ghibelli L. (1999): Magnetic fields increase cell survival by inhibiting apoptosis via modulation of $\mathrm{CaCC}$ influx. FASEB J. 13, 95-102

Feychting M., Ahlbom A., Kheifets L. (2005): EMF and health. Ann. Rev. Pub. Health 26, 165-189

http://dx.doi.org/10.1146/annurev.publhealth.26.021304.144445

Ghodbane S. (2011): Effets du champ magnétique statique sur le métabolisme du glucose, du sélénium et de la vitamine $\mathrm{E}$ chez le rat : rôle du stress oxydant et de l'apoptose. Ph.D. thesis, Carthage University, Tunisia.

Ghodbane S., Amara S., Arnaud J., Garrel C., Faure H., Favier A., Sakly M., Abdelmelek H. (2011a): Effect of selenium pretreatment on plasma antioxidant vitamins A (Retinol) and $\mathrm{E}$ ( $a$-Tocopherol) in static magnetic field-exposed rats. Toxicol. Ind. Health 27, 949-955 http://dx.doi.org/10.1177/0748233711401261

Ghodbane S., Amara S., Garrel C., Faure H., Favier A., Sakly M., Abdelmelek H. (2011b): Selenium supplementation ameliorates static magnetic field-induced disorders in antioxidant status in rat tissues. Environ. Toxicol. Phar. 31, 100-106 http://dx.doi.org/10.1016/j.etap.2010.09.010

Ghodbane S., Lahbib A., Sakly M., Abdelmelek H. (2013): Bioeffects of static magnetic fields: oxidative stress, genotoxic effects and cancer studies. Biomed. Res. Int. 2013

Goodman R., Blank M. (2002): Insights into electromagnetic interaction mechanisms. J. Cell Physiol. 192, 16-22 http://dx.doi.org/10.1002/jcp.10098

Hashish A. H., El-Missiry M. A., Abdelkader H. I., Abou-Saleh R. H. (2008): Assessment of biological changes of continuous whole body exposure to static magnetic field and extremely low frequency electromagnetic fields in mice. Ecotoxicol. Environ. Saf. 71, 895-902

http://dx.doi.org/10.1016/j.ecoenv.2007.10.002

Hong F. T. (1995): Magnetic field effects on biomolecules, cells, and living organisms. Biosystems 36, 187-229 http://dx.doi.org/10.1016/0303-2647(95)01555-Y

Joubert V., Bourthoumieu S., Leveque P., Yardin C. (2008): Apoptosis is induced by radiofrequency fields through the caspaseindependent mitochondrial pathway in cortical neurons. Radiat. Res. 169, 38-45 http://dx.doi.org/10.1667/RR1077.1

Kim H. J., Chang I. T., Heo S. J., Koak J. Y., Kim S. K., Jang J. H. (2005): Effect of magnetic field on the fibronectin adsorption, cell attachment and proliferation on titanium surface. Clin. Oral Implants Res. 16, 557-562 http://dx.doi.org/10.1111/j.1600-0501.2005.01164.x

Koppenol W. H. (2001): The Haber-Weiss cycle-70 years later. Redox Rep. 6, 229-234 http://dx.doi.org/10.1179/135100001101536373

Kula B., Sobczak A., Kuska R. (2000): Effects of static and ELF magnetic fields on free-radical processes in rat liver and kidney. Electromagn. Biol. Med. 19, 99-105 http://dx.doi.org/10.1081/JBC-100100300
Lalo U. V., Pankratov Y. O., Mikhailik O. M. (1994): Steady magnetic fields effect on lipid peroxidation kinetics. Redox Rep. $1,71-75$

Li J., Ma Y., Li N., Cao Y., Zhu Y. (2014): Natural static magnetic field-induced apoptosis in liver cancer cell. Electromagn. Biol. Med. 33, 47-50

http://dx.doi.org/10.3109/15368378.2013.783850

Lin T., Wan L., Qi X., Shi W., Lin J. (2014): A moderate static magnetic field enhances TRAIL-induced apoptosis by the inhibition of $\mathrm{Cdc} 2$ and subsequent downregulation of survivin in human breast carcinoma cells. Bioelectromagnetics 35, 337-346 http://dx.doi.org/10.1002/bem.21849

Loeffler M., Kroemer G. (2000): The mitochondrion in cell death control: certainties and incognita. Exp. Cell Res. 256, 19-26 http://dx.doi.org/10.1006/excr.2000.4833

Markesbery W. R. (1997): Oxidative stress hypothesis in Alzheimer's disease. Free Radic. Biol. Med. 23, 134-147 http://dx.doi.org/10.1016/S0891-5849(96)00629-6

Mohtat N., Cozens F. L., Hancock-Chen T., Scaiano J. C., McLean J., Kim J. (1998): Magnetic field effects on the behavior of radicals in protein and DNA environments. Photochem. Photobiol. 67, $111-118$ http://dx.doi.org/10.1111/j.1751-1097.1998.tb05173.x

Okano H. (2008): Effects of static magnetic fields in biology: role of free radicals. Front. Biosci. 13, 6106-6125 http://dx.doi.org/10.2741/3141

Pagliara P., Lanubile R., Dwikat M., Abbro L., Dini L. (2005): Differentiation of monocytic U937 cells under static magnetic field exposure. Eur. J. Hystochem. 49, 75-86

Placer Z. A., Cushman L. L., Johnson B. C. (1966): Estimation of product of lipid peroxidation (malonyldialdehyde) in biochemical systems. Anal. Biochem. 16, 359-364 http://dx.doi.org/10.1016/0003-2697(66)90167-9

Rosen A. D. (2003): Mechanism of action of moderate-intensity static magnetic fields. Biochem. Biophys. Acta 1282, 149-155 http://dx.doi.org/10.1016/0005-2736(96)00053-3

Saunders R. (2005): Static magnetic fields: animal studies. Prog. Biophys. Mol. Biol. 87, 225-239 http://dx.doi.org/10.1016/j.pbiomolbio.2004.09.001

Susin S. A., Zamzami N., Castedo M., Hirsch T., Marchetti P., Macho A., Daugas E., Geuskens M., Kroemer G. (1996): Bcl-2 inhibits the mitochondrial release of an apoptogenic protease. J. Exp. Med. 184, 1331-1341 http://dx.doi.org/10.1084/jem.184.4.1331

Tenuzzo B., Vergallo C., Dini L. (2009): Effect of $6 \mathrm{mT}$ static magnetic field on the bcl-2, bax, p53 and hsp70 expression in freshly isolated and in vitro aged human lymphocytes. Tissue Cell 4, 169-179

http://dx.doi.org/10.1016/j.tice.2008.09.004

Teodori L., Grabarek J., Smolewski P., Ghibelli L., Bergamaschi A., De Nicola M., Darzynkiewicz Z. (2002a): Exposure of cells to static magnetic field accelerates loss of integrity of plasma membrane during apoptosis. Cytometry 49, 113-118 http://dx.doi.org/10.1002/cyto.10160

Teodori L., Gohde W., Valente M. G., Tagliaferri F., Coletti D., Perniconi B., Bergamaschi A., Cerella C., Ghibelli L. (2002b): Static magnetic fields affect calcium fluxes and inhibit stress- 
induced apoptosis in human glioblastoma cells. Cytometry 49, 143-149 http://dx.doi.org/10.1002/cyto.10172

Teodori L., Albertini M. C., Uguccioni F., Falcieri E., Rocchi M. B., Battistelli M., Coluzza C., Piantanida G., Bergamaschi A., Magrini A. et al. (2006): Static magnetic fields affect cell size, shape, orientation, and membrane surface of human glioblastoma cells, as demonstrated by electron, optic, and atomic force microscopy. Cytometry A 69, 75-85 http://dx.doi.org/10.1002/cyto.a.20208

Walleczek J., Liburdy R. P. (1990): Nonthermal 60-Hz sinusoidal magnetic field exposure enhances $45 \mathrm{CaCC}$ uptake in rat thymocytes: dependence on mitogen activation. FEBS Lett. 271, $157-160$

http://dx.doi.org/10.1016/0014-5793(90)80396-Z
Zhang Q. M., Tokiwa M., Doi T., Nakahara T., Chang P. W., Nakamura N., Hori M., Miyakoshi J., Yonei S. (2003): Strong static magnetic field and the induction of mutations through elevated production of reactive oxygen species in Escherichia coli soxR. Int. J. Radiat. Biol. 79, 281-286 http://dx.doi.org/10.1080/0955300031000096289

Zmyslony M., Jajte J., Rajkowska E., Szmigielski S. (1998): Weak (5 mT) static magnetic field stimulates lipid peroxidation in isolated rat liver microsomes in vitro. Electromagnet. Biol. Med. 17, 109-113

http://dx.doi.org/10.3109/15368379809022556

Received: April 12, 2014

Final version accepted: August 26, 2014

First published online: November 14, 2014 